\title{
Molecular Survey of Tobacco Leaf Curl Virus Disease in Different Parts of Karnataka, India
}

\author{
Gurudevi V. Navali* and K.T. Rangaswamy \\ Department of Plant Pathology, University of Agricultural Sciences, GKVK, \\ Bengaluru-560065, Karnataka, India \\ *Corresponding author
}

\section{A B S T R A C T}

\begin{tabular}{|l|}
\hline K e y w or d s \\
$\begin{array}{l}\text { Tobacco, Leaf curl } \\
\text { disease, Survey, } \\
\text { Detection }\end{array}$ \\
\hline Article Info \\
\hline $\begin{array}{l}\text { Accepted: } \\
\text { 20 August } 2018 \\
\text { Available Online: } \\
\text { 10 September } 2018\end{array}$ \\
\hline
\end{tabular}

\section{Introduction}

Tobacco (Nicotiana spp.) belonging to family Solanaceae is one of the most important and widely grown commercial crop in both tropics and subtropics in the world. More than 70 species of tobacco are known, the chief commercial crop is Nicotiana tabacum and the more potent variant $N$. rustica is also used around the world. N. tabacum, an annually grown herbaceous plant and its leaves are commercially grown in many countries to be processed into tobacco. India is the second largest producer of tobacco after China, and shares about 11.42 per cent of world total production of 761.32 tonnes in a total area of 4.49 lack ha followed by Brazil (FAOSTAT,

\begin{abstract}
Surveys were conducted during 2016-18 revealed that the occurrence of the leaf curl disease on tobacco in major growing districts of Karnataka ranged from 19.60 to 31.01 during 2016-18. Among the six districts surveyed, highest per cent disease incidence of tobacco leaf curl virus was recorded in Shivamogga district (31.01) followed by Belagavi Chamarar the major diseases of tobacco. For the detection of the virus, total DNA was extracted and PCR was carried out using pair of begomovirus specific Deng primers. All the isolates collected at different locations showed characteristic band of $550 \mathrm{bp}$ whereas no amplicon was observed in healthy tobacco samples. This indicating the begomovirusis involved in causing the leaf curl disease in tobacco.
\end{abstract}


disease after the tobacco mosaic virus which is a limiting factor on crop growth and yield.

For the first time tobacco leaf curl disease was occurred in Indonesia in 1912 and then in Africa (Storey, 1931) and India (Pal and Tandon, 1937). Tobacco leaf curl virus (TbLCV) causes the most destructive disease of tobacco (Nicotiana tabacum) in India and substantial yield losses (Pal and Tandon, 1937; Reddy and Nagarajan, 1982).

The natural occurrence of the disease was observed by Pal and Tandon (1937) and Pruthi and Samuel (1937). Affected plants remain stunted, their leaves develop vein thickening, curling, veinal depressions and profuse enations. The virus is transmitted in nature by the whitefly Bemisiatabaci (Storey, 1931; Pruthi and Samuel, 1939, 1942 and Kiriyama, 1972).

The incidence of disease caused by tobacco leaf curl geminivirus (TbLCV) in ten tobacco growing areas of India ranged from 1.2 to 77 per cent. The highest incidence of disease was observed in Andhra Pradesh (77\%) followed by Gujarat (59\%), Karnataka (17\%), Bihar (11.6\%) and West Bengal (5.4\%) (Valand et al., 1992).

Tobacco leaf curl causing virus belongs to the genus Begomovirus, family Geminiviridae. The begomoviruses have either monopartite genome having one circular ssDNA component of about $2.7 \mathrm{~kb}$ designated as DNA-A, or bipartite genomes having two similar size components designated as DNA$\mathrm{A}$ and DNA-B. The DNA A genome contains four major genes encoding coat protein $(\mathrm{CP})$, replication initiator protein (Rep), transcriptional transactivator protein and replication enhancer protein. The DNA B contains two genes encoding proteins required for movement of virus, host range and pathogenicity.
In recent years, tobacco leaf curl virus is occurring regularly in India. In the present investigation, an attempt was made to know the incidence of the disease on tobacco in Karnataka and detection of presence of virus in the different tobacco leaf curl virus isolates.

\section{Materials and Methods}

\section{Survey and collection of isolates}

Surveys were carried out during the 20162017 and 2017-2108 in major tobacco growing areas of Karnataka, India to know the per cent disease incidence of leaf curl disease. The disease was diagnosed in the field based on symptoms exhibited on plants.

The per cent disease incidence was assessed by recording the number of plants showing disease symptoms, out of the total number of plants examined.

Diseased leaf samples of tobacco plants showing typical symptoms of begomovirus infection were collected and maintained under glasshouse. These collected isolates were inoculated to healthy tobacco seedlings with whiteflies. These inoculated plants were kept in insect proof glasshouse and observe for symptom expression.

The percentage of disease incidence was calculated by using the following formula (PDI).

Number of infected plants

Per cent disease incidence $=$------------ X 100

Total number of plants examined

Meanwhile, the leaves from the top of the plants that showing leaf symptoms were selected total DNA extraction and screened for the presence of begomovirus using begomovirus specific primers (Deng et al., 1994). 


\section{Total DNA extraction}

The total genomic DNA was extracted from leaf tissues of healthy and leaf curl infected tobacco plants of different isolates by C-TAB method (Doyle and Doyle, 1990). Infected plant tissue $(150 \mathrm{mg})$ was ground in a presterilized pestle and mortar using C-TAB buffer [100 mMTris ( $\mathrm{pH} 8.0$ ), $1.4 \mathrm{M} \mathrm{NaCl}, 20$ $\mathrm{mM}$ EDTA, $2 \%$ CTAB and $0.2 \%$ Mercaptoethanal] and transferred to sterile eppendorf tube and incubated for 1 hour in water bath at $65{ }^{\circ} \mathrm{C}$. The supernatant was collected into eppendorf tubes. To this added equal volumes of chloroform and Isoamyl alcohol (24:1) and mixed by vertexing. Then the tubes were centrifuged at $13,000 \mathrm{rpm}$ for $10 \mathrm{~min}$. The supernatant was collected and the DNA was precipitated by mixing with 0.1 volume of $7.5 \mathrm{M}$ ammonium acetate and 0.6 volume of chilled isopropanol then incubated at $-20{ }^{\circ} \mathrm{C}$ for overnight. After incubation, the tubes were taken out and centrifuged at 13,000 $\mathrm{rpm}$ for $10 \mathrm{~min}$. The supernatant was discarded and the pellet was washed with 70 $\%$ ethanol and again centrifuged at 13,000 rpm for $10 \mathrm{~min}$, the supernatant was discarded, vacuum dried for $10 \mathrm{~min}$ and re-suspended in $50 \mu \mathrm{l} \mathrm{T}_{10} \mathrm{E}_{1}$ buffer. Amplification of viral DNA by Polymerase Chain Reaction (PCR) PCR was performed using a pair of begomovirus universal primers. The forward and reverse primers were: Deng A 5, TAATATTACCKGWKGVCCSC -3 ' and Deng B 5'TGGACYTTRCAWGGBCCTTCACA -3', respectively (Deng et al., 1994).

\section{Results and Discussion}

\section{Incidence of the Tobacco Leaf Curl Virus (TbLCV) disease in major growing districts of Karnataka}

Major tobacco growing districts of Karnataka viz., Mysuru, Mandya, Chamarajnagar,
Shivamogga, Davanagere and Belagavi was surveyed to assess the disease incidence of TbLCV during 2016-17 and 2017-18. The details of the places surveyed, age of the crop, area covered, season of the crop, per cent disease incidence and symptoms observed during survey are presented in table 1 and 2 .

The symptoms under field conditions appeared as leaf curling, yellowing, production of leaf like outgrowths i.e., enation, twisting of stem and rarely petioles and finally stunting of the plant.

The average incidence of TbLCV disease ranged from 19.60to 31.01 during 2016-18. Among the six districts surveyed, highest per cent disease incidence of TbLCV was recorded in Shivamogga district (31.01) followed by Belagavi (25.59) and lowest per cent disease incidence of 19.60 of TbLCV was recorded in Chamarajangar district. In Mysuru district, the per cent disease incidence varied from 16.99 to 27.40 and highest incidence was observed in Hunsurutaluk (23.55 \%). In Mandya district, the per cent disease incidence varied from 18.13 to 21.22. In Chamarajangar district, the per cent disease incidence varied from 17.18 to 22.19. In Shivamogga district, the per cent disease incidence varied from 27.54 to 37.40. In Davanagere district, the per cent disease incidence varied from 19.36 to 23.08 and Belagavi district, the per cent disease incidence varied from 22.26 to 26.31 .

In the present study, natural occurrence of TbLCV disease varied among the districts surveyed. However, TbLCV disease was comparatively more in certain verities/hybrids where highest population of the whiteflies in that particular area. This could be attributed to the genetic composition of the cultivars grown in that area and the variation in the environmental conditions like temperature and relative humidity, vector population, cropping pattern and collateral natural hosts. 
Table.1 Average incidence of tobacco leaf curl virus disease (TbLCVD) in major tobacco growing districts of Karnataka during Kharif and Rabi seasons of 2016-18

\begin{tabular}{|c|c|c|c|c|c|c|c|}
\hline District & Taluk & Village & $\begin{array}{c}\text { Area } \\
\text { (acre) }\end{array}$ & $\begin{array}{c}\text { Age of the } \\
\text { crop } \\
\text { (DAT) }\end{array}$ & Varieties & $\begin{array}{c}\text { Disease } \\
\text { incidence } \\
(\%)\end{array}$ & Symptoms \\
\hline \multirow[t]{17}{*}{ Mysuru } & \multirow[t]{5}{*}{ H. D. Kote } & H. D Kote & 1.25 & 50 & Kanchan & 23.33 & LC, Y, EN, TW, ST \\
\hline & & Hanchipura & 1.00 & 55 & Kanchan & 21.97 & LC, Y, EN, ST \\
\hline & & Haliyuru & 1.00 & 50 & $\mathrm{CH} 3$ & 24.22 & LC, TW, ST \\
\hline & & Dadalli & 1.50 & 60 & Kanchan & 24.24 & LC, EN, TW, ST \\
\hline & & R. G. Hundi & 1.75 & 80 & Kanchan & 19.54 & LC, Y, EN, TW, ST \\
\hline & \multirow[t]{4}{*}{ Hunsuru } & Hunsuru & 5.00 & 75 & V-2 & 24.37 & LC, Y, ST \\
\hline & & Ramanahalli & 1.50 & 55 & $\mathrm{CH} 3$ & 27.40 & LC, Y, EN, TW \\
\hline & & Nilavagilu & 1.50 & 60 & $\mathrm{~V}-4$ & 19.67 & LC, Y, EN, TW, ST \\
\hline & & Hegganuru & 1.00 & 65 & V-5 & 22.77 & LC, Y, EN, TW, ST \\
\hline & \multirow[t]{5}{*}{ Piriyapatna } & Piriyapatna & 2.50 & 60 & Kanchan & 15.80 & LC, Y, ST \\
\hline & & Begur & 2.00 & 70 & Kanchan & 18.22 & LC, Y, EN, TW, ST \\
\hline & & Chilkunda & 1.50 & 65 & $\mathrm{CH} 3$ & 21.37 & LC, EN, TW, ST \\
\hline & & Kalkere & 1.75 & 70 & Kanchan & 18.94 & LC, Y, EN, TW, ST \\
\hline & & Kodihalli & 1.25 & 70 & K-323 & 17.69 & LC, Y, EN, TW, ST \\
\hline & \multirow[t]{3}{*}{ K. R. Nagar } & Krishnarajasagara & 1.50 & 65 & $\mathrm{~K}-323$ & 16.99 & LC, Y, EN, TW, ST \\
\hline & & Arjunahalli & 1.50 & 65 & $\mathrm{CH} 3$ & 18.43 & LC, EN, ST \\
\hline & & Akkihebbal & 1.50 & 75 & $\mathrm{CH} 3$ & 17.41 & LC, Y, EN, TW, ST \\
\hline \multirow[t]{4}{*}{ Mandya } & \multirow[t]{4}{*}{ K. R. Pet } & Bylapura & 1.00 & 70 & $\mathrm{FCH} 222$ & 18.95 & LC, Y, EN, TW, ST \\
\hline & & Honasoge & 1.25 & 60 & CH3 & 19.58 & LC, Y, EN, ST \\
\hline & & Saraguru & 1.00 & 65 & CH3 & 21.22 & LC, TW, ST \\
\hline & & Somanahalli & 1.75 & 70 & Kanchan & 18.13 & LC, Y, TW \\
\hline
\end{tabular}




\begin{tabular}{|c|c|c|c|c|c|c|c|}
\hline & & Madahalli & 1.25 & 75 & Kanchan & 19.79 & LC, Y, EN, TW, ST \\
\hline \multirow[t]{5}{*}{ Chamarajanagar } & \multirow{5}{*}{ Gundlupete } & Ankahalli & 1.50 & 70 & FCH222 & 22.19 & LC, Y, EN, TW, ST \\
\hline & & Beguru & 2.00 & 65 & Kanchan & 21.39 & LC, TW, ST \\
\hline & & Manchahalli & 1.50 & 55 & Kanchan & 17.18 & LC \\
\hline & & Shivapura & 1.00 & 75 & Kanchan & 17.30 & LC, ST \\
\hline & & Vaddarahalli & 1.25 & 80 & Kanchan & 19.99 & LC, Y, EN, TW, ST \\
\hline \multirow[t]{6}{*}{ Shivamogga } & \multirow[t]{6}{*}{ Shivamogga } & Shivamogga & 5.00 & 60 & $\mathrm{CH} 3$ & 37.40 & LC, Y, EN, TW, ST \\
\hline & & Abbalagere & 1.50 & 75 & $\mathrm{CH}$ & 27.54 & LC, Y, EN, TW \\
\hline & & Bannikere & 1.00 & 70 & Kanchan & 31.83 & LC, TW, ST \\
\hline & & Bithinahalli & 1.00 & 55 & $\mathrm{CH} 3$ & 31.50 & LC, Y, EN, ST \\
\hline & & HadonaHalli & 2.00 & 65 & FCH222 & 29.15 & LC, Y, EN, ST \\
\hline & & ThavareKoppa & 1.50 & 70 & FCH222 & 28.63 & LC, Y, EN, TW, ST \\
\hline \multirow[t]{5}{*}{ Davanagere } & \multirow[t]{5}{*}{ Honnali } & Jeenahalli & 2.00 & 65 & $\mathrm{CH} 3$ & 19.36 & LC, TW, ST \\
\hline & & Kenchikoppa & 1.75 & 60 & FCH222 & 23.08 & LC, Y, EN, TW, ST \\
\hline & & Kathige & 1.50 & 70 & $\mathrm{FCH} 222$ & 19.98 & LC, $\mathrm{ST}$ \\
\hline & & Kodikoppa & 1.50 & 65 & $\mathrm{CH} 3$ & 22.34 & LC, Y, EN, TW, ST \\
\hline & & Yankanahalli & 1.75 & 55 & $\mathrm{CH} 3$ & 20.13 & LC, EN, TW, ST \\
\hline \multirow[t]{6}{*}{ Belagavi } & \multirow[t]{6}{*}{ Chikkodi } & Nipani & 5.00 & 85 & NBD206 & 27.71 & LC, EN, TW \\
\hline & & Akkol & 2.00 & 70 & A119 & 26.30 & LC, TW \\
\hline & & Lakhanapur & 1.50 & 70 & Vedaganga & 26.31 & LC, EN, TW \\
\hline & & Mamadapur & 1.25 & 65 & Bhavyashree & 25.43 & LC, Y, EN, TW \\
\hline & & Sadalaga & 1.50 & 65 & Bhagyashree & 25.55 & LC, Y, EN, TW \\
\hline & & Sankanawadi & 1.50 & 80 & A119 & 22.26 & LC, Y, EN, TW \\
\hline
\end{tabular}

DAT: Days After Transplanting

Symptoms: LC=Leaf curl, Y=Yellowing, EN=Enation, TW=Twisting of the stem, ST=Stunting 
Table.2 Average disease incidence of tobacco leaf curl virus disease (TbLCVD) in major tobacco growing districts of Karnataka during 2016-18

\begin{tabular}{|c|c|c|c|}
\hline District & Taluk & $\begin{array}{c}\text { Average disease } \\
\text { incidence (\%) 2016-18 }\end{array}$ & $\begin{array}{c}\text { District wise A verage } \\
\text { disease incidence (\%) 2016- } \\
\text { (18 }\end{array}$ \\
\hline & H. D. Kote & 22.66 & 20.55 \\
\hline Mysuru & Hunsuru & 23.55 & \\
\hline & Piriyapatna & 18.40 & 19.67 \\
\hline & K. R. Nagar & 17.61 & 19.60 \\
\hline Mandya & K. R. Pet & 19.67 & 31.01 \\
\hline Chamarajanagar & Gundlupete & 19.60 & 20.97 \\
\hline Shivamogga & Shivamogga & 31.01 & 25.59 \\
\hline Davanagere & Honnali & 20.97 & \\
\hline Belagavi & Chikkodi & 25.59 & \\
\hline
\end{tabular}

Plate.1 Confirmation of tobacco leaf curl samples collected during survey for the presence of begomovirus through PCR by using Deng primers

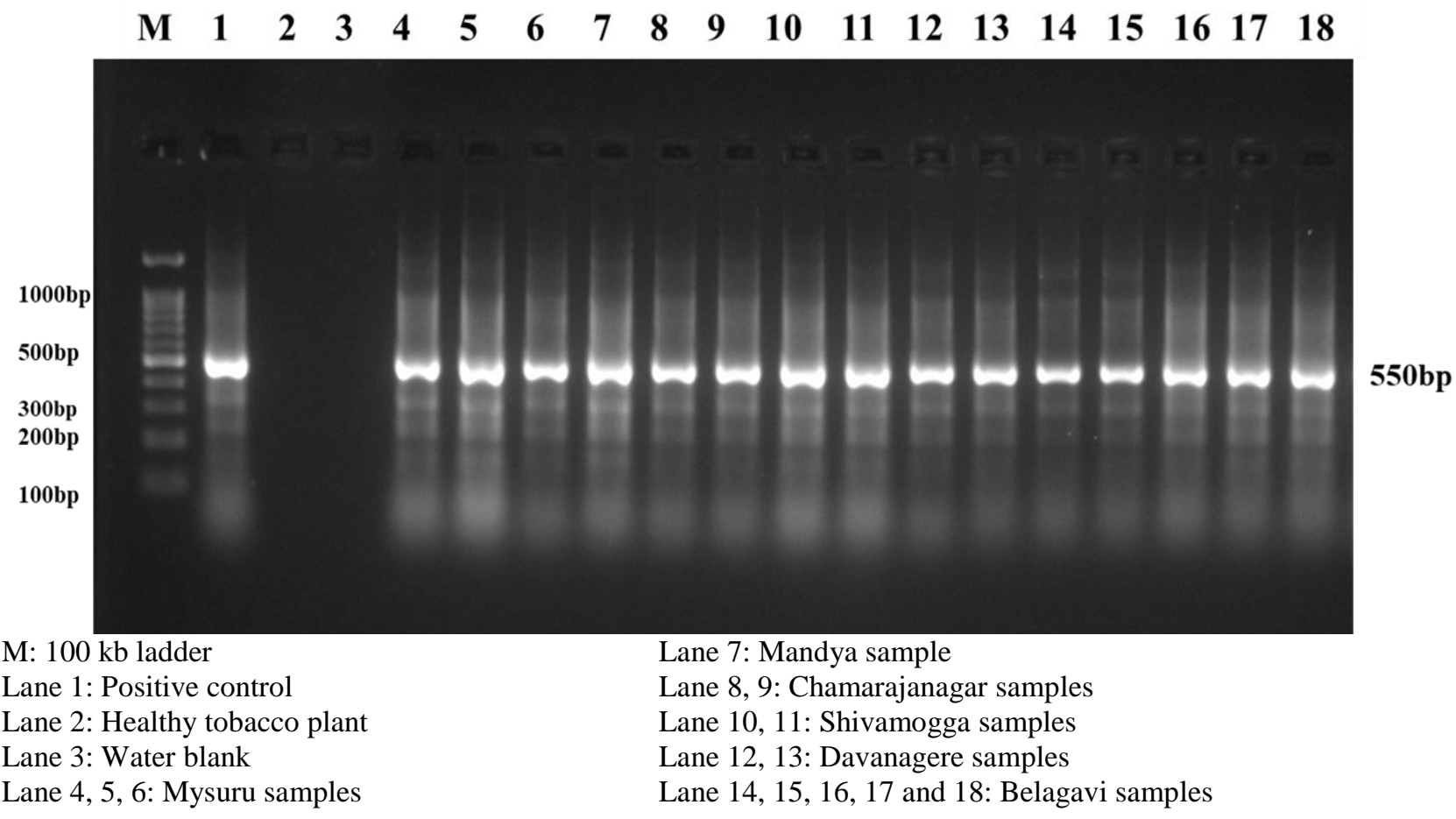

Similar results were recorded by Singh et al., (2011) who reported that, in the survey of tobacco growing areas in and around Pusa in 2007, 5-30 per cent incidence of Tobacco yellow leaf curl disease (TbYLCD) was observed. The incidence of disease caused by tobacco leaf curl geminivirus (TbLCV) in ten tobacco growing areas of India also been documented (Valand et al., 1992).

The highest incidence of disease was observed in Andhra Pradesh (77\%) followed 
by Gujarat (59\%), Karnataka (17\%), Bihar (11.6\%) and West Bengal (5.4\%).

\section{Detection of association of begomovirus in tobacco leaf curl isolates}

TbLCVD has been found to be caused by number of begomoviruses in India and elsewhere. It depends on the geminivirus prevailing in the location. A begomovirus specific degenerate Deng primers developed by Deng et al., (1994) to the conserved segment of DNA-A component of begomovirus. The amplication of $550 \mathrm{bp}$ which is very specific to begomoviruses. The primer set has been employed by the several workers for detection of many begomoviruses. In the present study, initially to find out association of begomovirus, total DNA was extracted from all the collected isolates. PCR was carried out pair of Deng primers. All the isolates collected at different locations showed characteristic band of 550 bp whereas no amplication was observed in healthy tobacco samples and water control (Plate 1), indicating the begomovirus involvement in causing the leaf curl disease in tobacco.

These results are on par with work done by Aswathanarayana et al., (2006) who used PCR technique to detect Jatropha Mosaic Virus (JMV) in Dodder and individual adult whiteflies of $B$. tabaci using Deng primers, which amplified the product of approximately $0.5 \mathrm{~kb}$ size. These results were on par with work done by Deepa (2016) who used PCR technique to detect tobacco leaf curl virus disease using Deng primers, which amplified the product of approximately $0.5 \mathrm{~kb}$ size. Similarly, Sinha et al., (2011) used the PCR technique for the detection of the pepper leaf samples collected from the plants showing typical curling symptom which was infected with pepper leaf curl virus (PLCV) for the presence of virus in diseased plant samples and the infected leaf DNA samples produced a typical $550 \mathrm{bp}$ amplification product and confirmed it to be a begomovirus.

In conclusion, the disease incidence of the tobacco leaf curl virus varied from one place to another place and detection of the virus using a Deng primers indicating the begomovirus is involved in the causing the tobacco leaf curl virus disease in Karnataka.

\section{References}

Anonymous, 2016, CA Report: Alternative uses for tobacco.

Aswathanarayana, D. S., Shankarappa, K. S., Prameela, H. A., Keshava Murthy, K. V. and Rangaswamy, K. T., 2006b, PCR detection of Jatropha mosaic virus in whitefly Bemisia tabaci and Dodder Cuscutasubinclusa. In: Inter. Sympo. management of vector-borne viruses, 7$10^{\text {th }}$ February 2006, ICRISAT, Hyderabad, 119 pp.

Deepa, T., 2016, Molecular survey and characterization of tobacco leaf curl virus infecting tobacco (Nicotiana tabacum L.). M.Sc. (Agri) Thesis, Univ. Agri. Sci., Bangalore, 59 pp.

Deng, D., Mcgrath, P. F., Robinson, D. J. and Harrison, B. D., 1994, Detection and differentiation of whitefly-transmitted geminiviruses in plants and vector insects by the polymerase reaction with degenerate primers. Ann. Appl. Biol., 125: 327-336.

Doyle, J. J. and Doyle, J. L., 1990, Isolation of plant DNA from fresh tissue. Focus, 12: $13-15$.

FAOSTAT, 2016, Crop Production. http://faostat.fao.org.

Kiriyama, K., 1972, Inoculation, purification and serology of tobacco leaf curl virus. Annals of the Phytopathological Society of Japan, 38: 322-332. 
Pal, B. P. and Tandon, R. N., 1937, Types of tobacco leaf curl in Northern India. Indian J. agric. Sci., 7: 363-393.

Paximadis, M., Muniyappa, V. and Rey, M. E. C., 2001, A mixture of begomoviruses in leaf curl-affected tobacco in Karnataka, South India. Ann. Appl. Biol., 139(1): 101-109.

Pruthi, H. S. and Samuel, C. K., 1937, Entomological investigations of the leaf curl disease of tobacco in North Bihar. Indian J. Agril Sci., 7: 659-670.

Pruthi, H. S. and Samuel, C. K., 1939, Entomological investigations of the leaf curl disease of tobacco in North Bihar. Indian J. Agril Sci., 9: 223-275.

Pruthi, H. S. and Samuel, C. K., 1942, Entomological investigations of the leaf curl disease of tobacco in North Bihar. Indian J. Agril Sci., 12: 35-37.

Reddy, T. S. N. and Nagarajan, K., 1982, Leaf curl disease on tobacco. Tobacco News, 5: 5-6.
Singh, M. K., Singh, K., Haq, Q. M., Mandal, B. and Varma, A., 2011, Molecular characterization of Tobacco leaf curl Pusa virus, a new monopartite Begomovirus associated with tobacco leaf curl disease in India. Virus genes, 43(2): 296-306.

Sinha, D.P., Saxena, S., Kumar, S. and Singh, M., 2011, Detection of pepper leaf curl virus through PCR amplification and expression of its coat protein in Escherichia coli for antiserum production. African J. Biotechnol., 10(17): 3290-3295.

Storey, H. H., 1931, A new virus disease of tobacco plant. Nature London, 128: 187-188.

Valand, G. B. and Muniyappa, V., 1992, Epidemiology of tobacco leaf curl in India. Ann. Appl. Biol., 120(2): 257267.

\section{How to cite this article:}

Gurudevi V. Navali and Rangaswamy, K.T. 2018. Molecular Survey of Tobacco Leaf Curl Virus Disease in Different Parts of Karnataka, India. Int.J.Curr.Microbiol.App.Sci. 7(09): 2857-2864. doi: https://doi.org/10.20546/ijcmas.2018.709.355 